\title{
LIPIDS AND LIPOPROTEINS IN DIABETIC ADOLESCENTS AND YOUNG ADULTS WITH RETINOPATHY
}

\author{
A. VERROTTI ${ }^{1}$, L. LOBEFALO ${ }^{2}$, F. CHIARELLI $^{1}$, L. MASTROPASQUA ${ }^{2}$, R. PALLOTTA $^{1}$, \\ L. COLANGELO ${ }^{2}$, G. MORGESE ${ }^{3}$ and P. E. GALLENGA ${ }^{2}$ \\ Chieti and Siena, Italy
}

\begin{abstract}
SUMMARY
Purpose: To compare serum concentrations of lipoproteins and apolipoproteins in insulin-dependent diabetic patients with and without retinopathy.

Methods: A cross-sectional study was performed on $\mathbf{4 2}$ diabetic adolescents and young adults with different degrees of retinopathy. The mean \pm SD age of the patient was 21.1 years (range 12.8-27.9 years); their mean duration of diabetes was 12.3 years (range 7.119.9 years). Their glycosylated haemoglobin $\left(\mathbf{H b A}_{1 c}\right)$ and fructosamine were respectively $10.2 \%(8.2-15.4 \%)$ and $280.8 \mu \mathrm{mol} / / \mathrm{l}(202.1-458.5 \mu \mathrm{mol} / \mathrm{l})$. Forty-two diabetics without retinopathy similar to the study population as regards age, sex, duration of disease, $\mathrm{HbA}_{1 \mathrm{c}}$ and microalbuminuria values, and 42 healthy subjects, served as controls.

Results: Serum lipid and lipoprotein concentrations were not different from those of healthy controls in patients either with or without retinopathy. The diabetic patients were subdivided in two groups according to the degree of their retinopathy: background and preproliferative/proliferative retinopathy. Patients with preproliferative/proliferative retinopathy were found to have significantly higher lipoprotein (a) values than the other group (background, 73.3 IU/; preproliferative/proliferative, 205.9 IU/; $p<0.001$ ).

Conclusion: The increase in lipoprotein (a) levels might play a role in the development of severe retinopathy.
\end{abstract}

Retinopathy has been described in about $90 \%$ of patients with insulin-dependent diabetes mellitus (IDDM) after 15 years of established disease; about $40 \%$ of IDDM patients will develop proliferative retinopathy after 30 years of disease. Several factors

From: Departments of ${ }^{1}$ Paediatrics and ${ }^{2}$ Ophthalmology, University of Chieti, Italy; ${ }^{3}$ Department of Pediatrics, University of Siena, Italy.

Correspondence to: Dr Lucio Lobefalo, Institute of Ophthalmology, via Gran Sasso 100, I-66100 Chieti, Italy. Tel: $(+39)$ 871358850. e-mail: lobefalo@unich.it. besides duration of disease have been shown to be associated with severe retinopathy, such as HLA haplotypes, degree of metabolic control and higher blood pressure. ${ }^{1-3}$ However, the cause of progression of retinopathy cannot be completely explained by $\mathrm{HbA}_{1 \mathrm{c}}$ and the other known parameters. ${ }^{4}$

Plasma lipid and lipoprotein patterns have been found to be deranged in patients with diabetes mellitus, ${ }^{5-13}$ and many recent reports have shown unaltered or abnormal levels of high density lipoprotein (HDL) cholesterol, low density lipoprotein (LDL) cholesterol and apolipoproteins in diabetic patients with retinopathy. ${ }^{14-17}$ The reports regarding the association of elevated serum lipid levels with different degrees of diabetic retinopathy are conflicting. It has been suggested that increased levels of serum lipids can be associated with severe exudative retinopathy; ${ }^{18}$ furthermore, higher lipid levels have been found in patients with retinopathy than in those without, ${ }^{19-21}$ suggesting that they may play a role in its development, but other investigators have failed to confirm this relationship.,14,15,22,23 In type 1 diabetic patients, high levels of serum cholesterol seem to be unrelated to diabetic retinopathy, whereas other authors have found high levels of serum triglycerides in patients with retinopathy. ${ }^{24-26}$

The present study was conducted to investigate the presence of changes in lipid and lipoprotein levels in type 1 diabetic patients with and without retinopathy.

\section{SUBJECTS AND METHODS}

\section{Subjects}

The trial included 42 adolescents and young adults with diabetic retinopathy of different degree, who were attending the regional Paediatric Diabetic Centre and the Department of Ophthalmology of the University of Chieti; 27 had background retinopathy and 15 preproliferative or proliferative retinopathy. 
The patients were selected according to the following criteria:

1. duration of disease greater than 5 years and Cpeptide (both basal and after glucagon stimulus) negative;

2. visual acuity greater than $20 / 40$;

3. clear dioptric media;

4. absence of other ocular pathologies;

5. absence of obesity defined as weight greater than $120 \%$ the average weight for height;

6. absence of thyroid, liver and metabolic diseases;

7. a fluorescein angiogram performed in the previous 3 months.

Forty-two sex- and age-matched diabetics without retinopathy and 42 sex- and age-matched healthy subjects were also enrolled using the same inclusion criteria (with the exception of point 7 for healthy controls). The demographic data of the evaluated groups are reported in Table I. The patients or their parents gave their informed consent to participate in the study.

Because it has been described that persistent microalbuminuria, duration of disease and glycosylated haemoglobin may have a role in the development of diabetic retinopathy and can modify serum lipids and lipoprotein values, ${ }^{27-29}$ the diabetic subjects without retinopathy were selected for their metabolic characteristics, which were not significantly different from those found in the group of patients with retinopathy: their $\mathrm{HbA}_{1 \mathrm{c}}$ was $9.8 \% \pm$ $5.5 \%(8.4 \%-15.3 \%)$ and fructosamine $281.8 \pm 176.5$ $\mu \mathrm{mol}$ (199-461) $\mu \mathrm{mol}$; the daily insulin requirement was similar in patients with retinopathy and controls. The $\mathrm{HbA}_{1 \mathrm{c}}$ values were calculated as the means of the values of the last year before the beginning of the study. The duration of disease of the control subjects was similar to that of diabetic patients with retinopathy, as well as the albumin excretion rate.

No patient in our study was taking substances such as oral contraceptives or other drugs that can influence serum lipid levels, and none of them smoked. None of the patients had severe hyperglycaemia (glycaemia ranged from 85 to $150 \mathrm{mg} / \mathrm{dl}$ ) or ketoacidosis at the time of sampling. All diabetics and controls had normal blood pressure.

All diabetics followed a optimised insulin regimen with three or four injections per day of human insulin. All diabetic patients had received standard dietary advice (isocaloric diet with adequate amount of carbohydrate and calories derived from about 55$60 \%$ carbohydrate, $30 \%$ fat and $12-15 \%$ protein). Moreover, specific advice concerning the usefulness of polyunsaturated fats in preference to animal fats and of fibre (roughage) in the diet had been given to all diabetics.

\section{Methods}

In all patients diabetic retinopathy was assessed by stereoscopic eye fundus photography and fluorescein angiography. Fluorescein angiography was performed with a Kowa RC-XF fundus camera after quick injection of $2 \mathrm{ml}$ of $20 \%$ sodium fluorescein into the antecubital vein. Angiograms were taken with ASA 400 black-and-white film developed at ASA 1200: retinopathy was classified into background, preproliferative or proliferative. ${ }^{30,31}$

The measurement of $\mathrm{HbA}_{1 \mathrm{c}}$ was performed by high-pressure liquid chromatography (HPLC; BioRad Laboratories, USA); fructosamine was measured by radioimmunoassay (RIA; Pharmacia, Sweden).

Table I. Relevant data and serum lipid and lipoprotein values of diabetes with and without retinopathy and controls

\begin{tabular}{|c|c|c|c|c|}
\hline & \multicolumn{2}{|c|}{ Diabetics } & \multirow[b]{2}{*}{ Controls } & \multirow[b]{2}{*}{$p$} \\
\hline & $\begin{array}{l}\text { Without } \\
\text { retinopathy }\end{array}$ & $\begin{array}{l}\text { With } \\
\text { retinopathy }\end{array}$ & & \\
\hline No. of patients & 42 & 42 & 42 & NS \\
\hline $\operatorname{Sex}(M: F)$ & $20: 22$ & $20: 22$ & 23:19 & NS \\
\hline Age (years) & $19.1 \pm 6.1$ & $21.1 \pm 5.6$ & $19.8 \pm 4.8$ & NS \\
\hline Body mass index $\left(\mathrm{kg} / \mathrm{m}^{2}\right)$ & $21.3 \pm 2.7$ & $21.1 \pm 2.5$ & $20.7 \pm 2.8$ & NS \\
\hline Duration of diabetes (years) & $11.1 \pm 8.8$ & $12.3 \pm 7.5$ & - & NS \\
\hline Insulin dose (U/kg/day) & $1.1 \pm 0.9$ & $1.02 \pm 0.7$ & - & NS \\
\hline Fructosamine $(\mu \mathrm{mo} / \mathrm{l})$ & $281.8 \pm 176.5$ & $280.8 \pm 177.9$ & _- & NS \\
\hline $\mathrm{HbA}_{1 \mathrm{c}}(\%)$ & $9.8 \pm 5.5$ & $10.2 \pm 5.1$ & - & NS \\
\hline Serum cholesterol $(\mathrm{mmol} / \mathrm{l})$ & $5.9 \pm 1.1$ & $5.7 \pm 1.3$ & $5.5 \pm 0.9$ & NS \\
\hline Serum triglycerides $(\mathrm{mmol} / \mathrm{l})$ & $1.4 \pm 0.7$ & $1.2 \pm 0.5$ & $1.1 \pm 0.6$ & NS \\
\hline LDL cholesterol $(\mathrm{mmol} / \mathrm{l})$ & $2.7 \pm 1.4$ & $2.4 \pm 1.6$ & $2.6 \pm 1.3$ & NS \\
\hline VLDL $(\mathrm{mmol} / \mathrm{l})$ & $0.6 \pm 0.3$ & $0.7 \pm 0.2$ & $0.5 \pm 0.2$ & NS \\
\hline HDL cholesterol $(\mathrm{mmol} / \mathrm{l})$ & $1.3 \pm 0.4$ & $1.3 \pm 0.3$ & $1.4 \pm 0.5$ & NS \\
\hline $\mathrm{HDL}_{2}$ cholesterol $(\mathrm{mmol} / \mathrm{l})$ & $0.9 \pm 0.7$ & $0.8 \pm 0.5$ & $0.8 \pm 0.4$ & NS \\
\hline $\mathrm{HDL}_{3}$ cholesterol $(\mathrm{mmol} / \mathrm{l})$ & $0.7 \pm 0.6$ & $0.8 \pm 0.4$ & $0.7 \pm 0.5$ & NS \\
\hline Lipoprotein (a) (IU/l) (range) & $90.9(29-910)$ & $110.7(27-1240)$ & $84.6(25-754)$ & NS \\
\hline Apolipoprotein B $(\mathrm{g} / \mathrm{l})$ & $1.07 \pm 0.9$ & $1.09 \pm 0.7$ & $1.04 \pm 0.9$ & NS \\
\hline Albumin excretion rate $(\mu \mathrm{g} / \mathrm{min})$ & $30.1 \pm 24.7$ & $40.8 \pm 15.7$ & - & NS \\
\hline
\end{tabular}

NS, not significant. 
Persistent microalbuminuria, a marker of incipient diabetic nephropathy, ${ }^{32}$ was defined as an albumin excretion rate greater than $20 \mu \mathrm{g} / \mathrm{min}$ and less than $200 \mu \mathrm{g} / \mathrm{min}$ in at least two of three consecutive overnight urine collections. Albumin excretion rate was measured as previously described. ${ }^{33}$

Lipids were measured in serum and the HDLcontaining supernatant after precipitation of apo B containing lipoproteins. Cholesterol and triglycerides were measured enzymatically, as previously described $^{31}$ using automated methods; LDL cholesterol was calculated by the Friedewald formula.

$\mathrm{HDL}$ and $\mathrm{HDL}_{3}$ were isolated by ultracentrifugation. ${ }^{34,35}$ The background density of plasma was adjusted to 1063 and $1125 \mathrm{~g} / \mathrm{l}$, respectively, by adding a sodium chloride-potassium bromide solution. The infranatants were obtained by tube slicing after ultracentrifugation at $100000 \mathrm{~g}$ for 48 hours (L8M55 ultracentrifugation with $50.3 \mathrm{Ti}$ rotor; Beckman). The concentration of cholesterol in $\mathrm{HDL}_{2}$ was determined by subtracting $\mathrm{HDL}_{3}-$ cholesterol from total HDL-cholesterol. ${ }^{36}$

In view of the possibility that lipoprotein (a) might interfere with the isolation of HDL by ultracentrifugation, HDL was also isolated by precipitation of other lipoproteins, including lipoprotein (a), with sodium phosphotungstate and magnesium chloride. ${ }^{37,38}$ Total serum apolipoprotin B concentrations were determined by immunoelectrophoresis using goat-antiserum (Immuno, Dunton Green, Kent, UK). The within-batch coefficient of variation of the assay was $5.4 \%$.

Serum lipoprotein (a) concentrations were measured using a two-site radioimmunometric assay (Pharmacia Diagnostics, Sweden). After hydrolysis and dilution, the serum sample was incubated with an excess of ${ }^{125}$ I-labelled anti-apo (a) monoclonal antibody and a different monoclonal antibody coupled to micro-Sepharose. Antibody-antigen complexes were separated from unbound ${ }^{125}$ I by centrifugation and their radioactivity was measured. A standard curve was drawn for each assay. The withinand between-assay coefficients of variation were $6 \%$ and $8 \%$, respectively. Results are expressed in terms of the Pharmacia standard and are in units per litre.

\section{Statistical Analysis}

Results are expressed as the mean $\pm \mathrm{SD}$ or medians and ranges for data not normally distributed; $p$ values less than 0.05 were considered significant. All variables measured were checked for normality and the comparisons of data among groups were performed by analysis of variance for parametrically and non-parametrically distributed data, as appropriate. Adjustment for multiple comparisons was carried out using Duncan's method.

\section{RESULTS}

Serum lipid and lipoprotein concentrations were similar in the two diabetic subgroups and in healthy controls. In particular, the patients without retinopathy and those with retinopathy showed no significant difference in lipoprotein (a) levels when compared with the healthy controls $(90.9 \mathrm{IU} / \mathrm{l}$, range 29-910 IU/l in subjects without retinopathy; 110.7 IU/l, range $27-1240 \mathrm{IU} / \mathrm{l}$ in subjects with retinopathy; $84.6 \mathrm{IU} / \mathrm{l}$, range $25-754 \mathrm{IU} / \mathrm{l}$ in healthy controls). Table I shows a comparison of the levels of serum lipids and lipoproteins between diabetic patients with and without retinopathy and controls.

Table II shows the data of the retinopathy groups, classified according to the severity of retinopathy as either background or preproliferative/proliferative retinopathy. Comparing the levels of plasma lipids and lipoproteins in the retinopathy subgroups, we observed similar data in the two groups except for

Table II. Relevant data and serum lipid and lipoprotein values of diabetics with background and preproliferative/proliferative retinopathy

\begin{tabular}{|c|c|c|}
\hline & $\begin{array}{l}\text { Background } \\
\text { retinopathy }\end{array}$ & $\begin{array}{l}\text { Preproliferative/ } \\
\text { proliferative retinopathy }\end{array}$ \\
\hline No. of patients & 27 & 15 \\
\hline Age (years) & $20.1 \pm 5.7$ & $23.0 \pm 6.4$ \\
\hline Body mass index $\left(\mathrm{kg} / \mathrm{m}^{2}\right)$ & $21.5 \pm 2.9$ & $21.9 \pm 2.0$ \\
\hline Duration of diabetes (years) & $11.8 \pm 6.5$ & $16.9 \pm 7.5^{\mathrm{a}}$ \\
\hline Insulin dose (U/kg/day) & $1.02 \pm 0.8$ & $1.05 \pm 0.6$ \\
\hline Fructosamine $(\mu \mathrm{mol} / \mathrm{l})$ & $280 \pm 175$ & $282 \pm 173$ \\
\hline $\mathrm{HbA}_{1 \mathrm{c}}(\%)$ & $10.3 \pm 4.9$ & $10.1 \pm 5.2$ \\
\hline Serum cholesterol (mmol/l) & $5.6 \pm 1.4$ & $5.8 \pm 1.4$ \\
\hline Serum triglycerides $(\mathrm{mmol} / \mathrm{l})$ & $1.2 \pm 0.5$ & $1.3 \pm 0.5$ \\
\hline LDL cholestrol (mmol/l) & $2.4 \pm 1.7$ & $2.5 \pm 1.6$ \\
\hline $\operatorname{VLDL}(\mathrm{mmol} / \mathrm{l})$ & $0.8 \pm 0.4$ & $0.7 \pm 0.4$ \\
\hline HDL cholesterol (mmol/l) & $1.4 \pm 0.3$ & $1.2 \pm 0.3$ \\
\hline $\mathrm{HDL}_{2}$ cholesterol $(\mathrm{mmol} / \mathrm{l})$ & $0.9 \pm 0.6$ & $1.0 \pm 0.4$ \\
\hline $\mathrm{HDL}_{3}$ cholesterol $(\mathrm{mmol} / \mathrm{l})$ & $0.7 \pm 0.5$ & $0.9 \pm 0.4$ \\
\hline Lipoprotein (a) (IU/1) (range) & $73.3(29-812)$ & $205.9(57-1240)^{\mathrm{b}}$ \\
\hline Apolipoprotein B (g/l) & $1.09 \pm 0.9$ & $1.08 \pm 0.8$ \\
\hline Albumin excretion rate $(\mu \mathrm{g} / \mathrm{min})$ & $37.3 \pm 18.3$ & $47.2 \pm 20.6$ \\
\hline
\end{tabular}


Table III. Relevant data and serum lipid and lipoprotein values of matched subjects (diabetics without and with preproliferative/ proliferative retinopathy)

\begin{tabular}{|c|c|c|}
\hline & $\begin{array}{l}\text { Without } \\
\text { retinopathy }\end{array}$ & $\begin{array}{l}\text { Preproliferative/ } \\
\text { proliferative retinopathy }\end{array}$ \\
\hline No. of patients & 15 & 15 \\
\hline Age (years) & $22.4 \pm 4.8$ & $23.0 \pm 6.4$ \\
\hline Body mass index $\left(\mathrm{kg} / \mathrm{m}^{2}\right)$ & $20.3 \pm 2.7$ & $21.9 \pm 2.0$ \\
\hline Duration of diabetes (years) & $15.4 \pm 7.2$ & $16.9 \pm 7.5$ \\
\hline Insulin dose $(\mathrm{U} / \mathrm{kg} / \mathrm{day})$ & $1.01 \pm 0.9$ & $1.05 \pm 0.6$ \\
\hline Fructosamine $(\mu \mathrm{mol} / \mathrm{l})$ & $299.5 \pm 199$ & $282 \pm 173$ \\
\hline $\mathrm{HbA}_{1 \mathrm{c}}(\%)$ & $10.5 \pm 5.1$ & $10.1 \pm 5.2$ \\
\hline Serum cholesterol (mmol/l) & $5.9 \pm 1.9$ & $5.8 \pm 1.4$ \\
\hline Serum triglycerides $(\mathrm{mmol} / \mathrm{l})$ & $1.5 \pm 0.8$ & $1.3 \pm 0.5$ \\
\hline LDL cholesterol $(\mathrm{mmol} / \mathrm{l})$ & $2.8 \pm 1.8$ & $2.5 \pm 1.6$ \\
\hline VLDL $(\mathrm{mmol} / \mathrm{l})$ & $0.8 \pm 0.6$ & $0.7 \pm 0.4$ \\
\hline HDL cholesterol (mmol/l) & $1.4 \pm 0.7$ & $1.2 \pm 0.3$ \\
\hline $\mathrm{HDL}_{2}$ cholesterol $(\mathrm{mmol} / \mathrm{l})$ & $0.8 \pm 0.7$ & $1.0 \pm 0.4$ \\
\hline $\mathrm{HDL}_{3}$ cholesterol $(\mathrm{mmol} / \mathrm{l})$ & $0.8 \pm 0.6$ & $0.9 \pm 0.4$ \\
\hline Lipoprotein (a) (IU/l) (range) & $99.5(68-910)$ & $205.9(57-1240)^{\mathrm{a}}$ \\
\hline Apolipoprotein B (g/l) & $1.08 \pm 0.9$ & $1.08 \pm 0.8$ \\
\hline Allbumin excretion rate $(\mu \mathrm{g} / \mathrm{min})$ & $38.6 \pm 25.8$ & $47.2 \pm 20.6$ \\
\hline
\end{tabular}

${ }^{\mathrm{a}} p=0.001$ versus subjects without retinopathy.

the lipoprotein (a) levels (background: $73.3 \mathrm{IU} / \mathrm{l}$; preproliferative/proliferative: $205.9 \mathrm{IU} / \mathrm{l}$ ), which were significantly higher in patients with preproliferative/ proliferative retinopathy than in the background retinopathy group $(p<0.001)$.

In order to exclude the possibility that the increased lipoprotein (a) concentration could be due to the long duration of disease of the retinopathic diabetics, we compared diabetic patients with proliferative retinopathy with a selected group of 15 diabetics without retinopathy with the same duration of disease (Table III). In this comparison we found higher lipoprotein (a) levels in the retinopathic group than in the matched group without retinopathy $(p<0.001)$.

\section{DISCUSSION}

In the present study we evaluated the principal lipid parameters in order to detect any possible abnormalities in diabetics with retinopathy.

Patients with retinopathy and persistent microalbuminuria frequently show a long duration of disease and/or high glycosylated haemoglobin levels. ${ }^{39}$ To avoid the interference of these two variables in the assessment of our data, we selected a diabetic control population without retinopathy who had the same duration of disease and quality of metabolic control as the diabetics with retinopathy; moreover, these two groups of diabetic patients had the same albumin excretion rate.

Our study shows that diabetic patients with retinopathy do not have any significant difference in serum levels of lipids and lipoproteins (a) when compared with patients without retinopathy and normal subjects. These data are in agreement with those of some other authors. ${ }^{6,14,24,25,40,41}$ In particular, Agardh et al. ${ }^{14}$ found no significant difference in the levels of cholesterol, triglycerides, HDL cholest- erol and LDL cholesterol between patients with established proliferative retinopathy and patients without retinopathy. While the patients studied by Agardh et al. ${ }^{14}$ had similar insulin doses and did not differ regarding metabolic control as reflected by $\mathrm{HbA}_{1 \mathrm{c}}$ levels, in the study by Hanna et $a .^{24}$ the patients with proliferative retinopathy had higher insulin doses as well as higher $\mathrm{HbA}_{1 \mathrm{c}}$ levels. Moreover, our study is also in agreement with Mohan et $a .^{21}$ and Lapolla et $a l^{42}$ and does not support the assumption that increased levels of serum triglycerides are associated with retinopathy. In contrast, other authors obtained different results: Dornan et $a l^{43}$ showed that total cholesterol levels were higher in patients with proliferative retinopathy compared with background or no retinopathy, due to raised levels of LDL cholesterol, and Winocur et al..$^{34}$ and Ritter et $a l^{44}$ found significant lipoprotein (a) abnormalities in diabetic patients with retinopathy.

In our study, when the patients were subdivided into two groups according to the severity of their retinopathy, we found that diabetic subjects with preproliferative/proliferative retinopathy tended to have higher serum lipoprotein (a) levels than those with background retinopathy, in spite of similar metabolic control and insulin requirement. This difference cannot be explained by differences in blood glucose control, since the $\mathrm{HbA}_{1 \mathrm{c}}$ concentration was comparable in the two groups. Moreover, the two groups of diabetics showed similar values of albumin excretion rate; these data exclude the possibility that the increased lipoprotein (a) can be due to the persistent microalbuminuria, as suggested by other studies. ${ }^{16,44}$ The disease duration of diabetic patients with proliferative/proliferative retinopathy was significantly longer than that of background retinopathy patients, as found in other studies, ${ }^{14,16}$ but the most important factor ${ }^{14,16,24,25}$ that can affect 
the concentration of lipoprotein (a) is the quality of metabolic control, ${ }^{26}$ not the duration of disease. However, we compared the patients with proliferative retinopathy with matched subjects (with comparable duration of disease) from the group of diabetic patients without retinopathy; this comparison allowed us to exclude the possibility that the increased lipoprotein (a) concentration was due to a longer duration of disease. These data are in agreement with those of Maioli et al. ${ }^{16}$ and Kostraba et $a l .{ }^{45}$ but not with those of Sinav et al. ${ }^{23}$ In particular, Maioli et al. ${ }^{16}$ found that serum lipoprotein (a) was higher in the patients with active retinopathy than in those without clinically detectable retinal lesion; there were no differences for total and HDL cholesterol, triglycerides or apoliproteins $\mathrm{A} 1$ and B between diabetics with and without retinal lesions.

According to the Wisconsin Epidemiologic Study of Diabetic Retinopathy, ${ }^{46}$ severity of retinopathy is related to long duration of disease, high levels of glycosylated haemoglobin, presence of proteinuria, high diastolic blood pressure and male sex; our study added to these risk factors the high level of lipoprotein (a), which may play a role in the development of severe retinopathy.

Nevertheless, our results seem to be particularly noteworthy in view of the structural similarity between lipoprotein (a) and plasminogen, ${ }^{47}$ and a possible involvement of lipoprotein (a) in capillary occlusion. ${ }^{44,48}$ In fact, lipoprotein (a) may contribute to the development of severe retinopathy. If this hypothesis is confirmed, it will improve our knowledge on the pathogenesis of diabetic retinopathy and enable us to identify a group of patients who are at risk of developing this severe microvascular complication.

Key words: Type I diabetes, Lipoprotein (a), Retinopathy.

\section{REFERENCES}

1. Chiumello G, Bognetti E, Meschi E, Carrà M, Balzano E. Early diagnosis of subclinical complications in insulin dependent diabetic children and adolescents. J Endocrinol Invest 1989;12(Suppl 3):101-4.

2. Rand LI, Krolewski AS, Aiello LM, Warram JH, Baker RS, Maki T. Multiple factors in the prediction of risk of proliferative diabetic retinopathy. N Engl J Med 1985;313:1433-7.

3. Dahl-Jørgensen K, Brinchmann-Hansen O, Hanssen KF, Ganes T, Kieruf P, Smeland E, et al. Effect of near normoglycemia for two years on progression of early diabetic retinopathy, nephropathy and neuropathy: the Oslo Study. BMJ 1986;29:1195-9.

4. Morisaki N, Yokote K, Tashiro J, Inadera H, Kobayashi J, Kanzaki T, et al. Lipoprotein (a) is a risk factor for diabetic retinopathy in the elderly. J Am Geriatr Soc 1994;42:965-7.

5. Vannini P, Ciavarella A, Flammini M. Lipid abnormalities in insulin-dependent diabetic patients with albuminuria. Diabetes Care 1984;7:151-4.
6. Dullaart RPF, Dikkeschei LD, Doorenbos H. Alterations in serum lipids and apoliproteins in male Type 1 (insulin-dependent) diabetic patients with microalbuminuria. Diabetologia 1989;32:685--9.

7. Sosenko JM, Breslow JL, Miettinen OS, Gabbay KH. Hyperglycemia and plasma lipid levels: a prospective study of young insulin-dependent diabetic patients. $\mathrm{N}$ Engl J Med 1980;302:650-4.

8. Durrington PN. Serum high density lipoprotein cholesterol in diabetes mellitus: an analysis of factors which influence its concentration. Clin Chim Acta 1980;104:11-23.

9. Eckel RH, Albers JJ, Cheung MC, Wahl PW, Lindgren FT, Bierman EL. High density lipoprotein composition in insulin dependent diabetes mellitus. Diabetes 1981;30:132-8.

10. Lopes-Virella MF, Wohltmann HJ, Loadholtt CB, Buse MG. Plasma lipids and lipoproteins in young insulin-dependent diabetic patients: relationship with control. Diabetologia 1981;21:216-23.

11. Laakso M, Voutilainen E, Sarlund H, Aro A, Pyörälä $\mathrm{K}$, Penttila I. Inverse relationship of serum HDL and $\mathrm{HDL}_{2}$ cholesterol to C-peptide level in middle-aged insulin-treated diabetics. Metabolism 1985;34:715-20.

12. Winocur PH, Durrington DN, Ishola M, Andersen DC. Lipoprotein abnormalities in insulin-dependent diabetes mellitus. Lancet 1986;I:1176-8.

13. Weisweiler P, Schwandt P. Type 1 (insulin-dependent) versus Type 2 (non-insulin-dependent) diabetes mellitus: characterisation of serum lipoprotein alterations. Eur J Clin Invest 1987;17:87-91.

14. Agardh CD, Agardh E, Bauer B, Nilsson-Ehle P. Plasma lipids and lipoproteins in diabetics with and without proliferative retinopathy. Acta Med Scand 1988;223:165-9.

15. Dihr SP, Dahiya R, Ram J, Dash RJ, Chakravarti RN. Serum lipoprotein cholesterol profile in diabetic retinopathy. Indian J Ophthalmol 1984;32:89-91.

16. Maioli M, Tonolol G, Pacifico A, Ciccarese M, Brizzi P, Kohner EM, Porta M. Raised serum apolipoprotein (a) in active diabetic retinopathy. Diabetologia 1993;36: 88-90.

17. Laakso M, Sarlund H, Ehnholm C, Voutilainen E, Aro A, Pyörälä K. Relationship between postheparin plasma lipases and high-density lipoprotein cholesterol in different types of diabetes. Diabetologia 1987;30: 703-6.

18. Brown GC, Ridley M, Haas D, Lucier AC, Sarin LK. Lipemic diabetic retinopathy. Ophthalmology 1984;91: 1490-505.

19. Constable IJ, Welborn TA, Cooper RL. Medical correlates and diabetic retinopathy and nephropathy in diabetes. Diabetes 1980;100:78-82.

20. Kissebah AH, Kohner EM, Lewis B, Sidding YK, Lowy YK, Fraser TR. Plasma lipids and glucose/insulin relationship in non-insulin-requiring diabetics with and without retinopathy. Lancet 1975;I:1104-8.

21. Mohan R, Mohan V, Susheela L, Ramachandran A, Viswanathan M. Increased LDL cholesterol in noninsulin-dependent diabetics with maculopathy. Acta Diabetol 1984;21:85-9.

22. Jialal I, Joubert SM. The biochemical profile in Indian patients with non-insulin-dependent diabetes in the young with retinopathy. Diabet Metab 1985;11:262-5.

23. Sinav S, Onelge MA, Onelge S, Sinva B. Plasma lipid and lipoproteins in retinopathy of type 1 (insulindependent) diabetic patients. Ann Ophthalmol 1993;25:64-6. 
24. Hanna AK, Roy M, Zinman B. An evaluation of factors associated with proliferative diabetic retinopathy. J Clin Invest 1985;8:109-16.

25. Weber B, Burger W, Hartmann R, Hövener G, Malchus R, Oberdisse U. Risk factors for the development of retinopathy in children and adolescents with Type 1 (insulin-dependent) diabetes mellitus. Diabetologia 1986;29:23-9.

26. Bhatnagar D, Ishola M, Arrol S, Durrington PN. Lipoprotein (a) and microvascular disease in Type 1 (insulin-dependent) diabetes. Diabetic Med 1991;8: 922-7.

27. Dullaart RPF, Ramirez LC, Arauz-Pacheco C, Lackner C, Albright G, Adams BV, Raskin P. Lipoprotein (a) levels in diabetes mellitus: relationship to metabolic control. Ann Intern Med 1992;117:42-7.

28. Verrotti A, Lobefalo L, Chiarelli F, Gallenga PE, Morgese G. Diabetic retinopathy: relationship with retinopathy in pediatric age. PanMinerva Med 1994;36:179-83.

29. Verrotti A, Chiarelli F, Tumini S, Morgese G. Serum lipids, microalbuminuria and metabolic control in diabetic children. Acta Diabetol Lat 1991;28:99-104.

30. Klein BEK, Davis MD. Diabetic retinopathy: assessment of severity and progression. Ophthalmology 1984;91:10-4.

31. Verrotti A, Chiarelli F, Morgese G. Influence of puberty on lipids and lipoprotein profile in children with Type 1 diabetes mellitus. Acta Diabetol 1995;32:102-5.

32. Chiarelli F, Verrotti A, La Penna G, Morgese G. Low serum $\mathrm{C} 4$ levels in type 1 diabetes mellitus. Eur J Pediatr 1988;147:197-8.

33. Mogensen CE, Christensen CK. Predicting diabetic nephropathy in insulin-dependent patients. N Engl J Med 1984;311:89-93.

34. Winocur PH, Bhatnagar D, Ishola M, Arrol S, Durrington PN. Lipoprotein (a) and microvascular disease in type 1 (insulin-dependent) diabetes. Diabetic Med 1991;8:922-7.

35. Havel RJ, Eder HA, Bragdon JH. The distribution and chemical composition of ultracentrifugally separated lipoproteins in normal serum. $\mathrm{J}$ Clin Invest 1955;34:1345-53.

36. Durrington PN. Serum high density lipoprotein cholesterol subfractions in type 1 (insulin-dependent) diabetes mellitus. Clin Chim Acta 1982;120:21-8.
37. Burstein M, Scholnick HR, Morfin R. Rapid method for the isolation of lipoproteins from human serum by precipitation with polyanions. J Lipid Res 1970;11:583-95.

38. Kostner GM. Apolipoprotein and lipoproteins of human plasma: significance in health and in disease. Adv Lipid Res 1983;20:1-43.

39. The Diabetes Control and Complications Trial Study Group. The effect of intense treatment of diabetes on the development and progression of long-term complications in insulin-dependent diabetes mellitus. $\mathrm{N}$ Engl J Med 1993;329:977-87.

40. Maser RE, Usher D, Becker DJ, Drash AL, Kuller LH, Orchard TJ. Lipoprotein (a) concentration shows little relationship to IDDM complications in the Pittsburgh Epidemiology of Diabetes Complications study cohort. Diabetes Care 1993;16:755-8.

41. Ramirez LC, Arauz-Pacheco C, Lackner C, Albright G, Adams BV, Raskin P. Lipoprotein (a) levels in diabetes mellitus: relationship to metabolic control. Ann Intern Med 1992;117:42-7.

42. Lapolla A, Poli T, Valerio A, Fedele D. Glycosylated serum proteins in diabetic patients and their relation to metabolic parameters. Diabete Metab 1985;11:238-42.

43. Dornan TL, Carter RD, Bron AJ, Turner RC, Mann JI. Low density lipoprotein cholesterol: an association with the severity of diabetic retinopathy. Diabetologia 1982;22:167-70.

44. Ritter MM, Loscar M, Richter WO, Schwandt P. Lipoprotein (a) in diabetes mellitus. Clin Chim Acta $1993 ; 214: 45-54$.

45. Kostraba JN, Klein R, Dorman JS, Becker DJ, Drash AL, Maser RE, Orchard TJ. The epidemiology of diabetes complications study. IV. Correlates of diabetic background and proliferative retinopathy. Am J Epidemiol 1991;133:381-91.

46. Klein R, Klein BEK, Moss SE, Davis D, DeMets DL. The Wisconsin Epidemiologic Study of Diabetic Retinopathy. II. Prevalence and risk of diabetic retinopathy when age at diagnosis is less than 30 years. Arch Ophthalmol 1984;102:520-6.

47. McLean JW, Tomlison JE, Kuang WJ. cDNA sequence of human apolipoprotein (a) is homologous to plasminogen. Nature 1987;300:132-7.

48. Mbewu AD, Durrington PN. Lipoprotein (a): structure, properties and possible involvement in thrombogenesis and atherogenesis. Atherosclerosis 1990;85: $1-14$. 